\title{
Food Security Status and Its Determinant Factors in Central Ethiopia: Empirical Evidence from Walmara District
}

\author{
Gadisa Muleta $^{1} \quad$ Addisu Getahun $^{2}$ \\ 1.Ethiopian Institute of Agricultural Research (EIAR), National Agricultural Biotechnology Research Center \\ (NABRC), P.O. Box. 249, Holeta, Ethiopia \\ 2.Ethiopian Institute of Agricultural Research (EIAR), Holeta Agricultural Research Center \\ (HARC), P.O. Box. 31, Holeta, Ethiopia
}

\begin{abstract}
The study was conducted with the objective of assessing factors associated with farm households' food security status using primary data collected from 220 sample households from Walmara district, central Ethiopia. The multistage sampling technique was the sampling procedure followed to take the required sample. Descriptive and econometric data analyses were executed. The descriptive result revealed that sex of the head, access to credit services, access to extension contact, educational level of the household head, livestock holding, and land owned were positively related, while the occurrence of crop pests, age of the household head, dependency ratio, family size, market distance, and irrigation distance negatively related to household food security status. Logistic regression was the model used, and the result revealed that sex of the household head, livestock holding, land owned, access to extension contacts, access to irrigation services, and access to credit services showed a positive association, while the family size and dependency ratio negatively and significantly associated with household foods security status. Therefore, policies and strategies focusing on the provision of gender-based training, establishing irrigation facilities, promoting mixed farming of crop and livestock, and availing institutional facilities that providing financial and technical services to farm households are recommended as they contribute more in improving the food security status of farm households.
\end{abstract}

Keywords: Food security, Calorie, logistic regression, Walmara

DOI: $10.7176 / \mathrm{FSQM} / 108-03$

Publication date:May $31^{\text {st }} 2021$

\section{INTRODUCTION}

The problems of food insecurity and hunger are the predicaments that are challenging the world, in which close to 750 million people were in the state of severe food insecurity during 2019. This figure is clearly showing that the world is not on the track of achieving zero hunger, and if the current trends are not reversed, the number of people affected by hunger will surpass 840 million by 2030, out of which 52 percent from Africa. Conflicts, climate variability, economic slowdowns and recessions, the pandemic covid-19, and the outbreak of the desert locusts are the primary drivers undermining the efforts to end hunger, food insecurity, and malnutrition during recent years (FAO et al., 2020).

The problem of food insecurity and hunger can increase the risk of various forms of malnutrition. According to FAO et al (2020), 144 million children under 5 years were stunted, 47 million were wasted, 38.3 million were overweight, and more than 340 million were suffering from micronutrient deficiencies.

The problems of food and nutritional insecurity are even worse in Africa, as the larger population mainly depends on agriculture (World Bank, 2018; World Vision, 2018) and the rate of population growth far exceeds the rate at which both the quantity and quality of food production required to sustain the population growth is growing, particularly in sub-Saharan Africa. About 257 million people were hungry in the continent, out of which 237 million were from sub-Sahara. Moreover, the prevalence of undernourished people in the region is alarmingly increasing and was more than 236 million during 2017 (FAO et al., 2018; FAO and ECA, 2018).

In Ethiopia, food and nutritional insecurity are persistent and critical challenges for decades and the country is still among the poorest countries in the world ranked 179th out of 189 nations. According to FAO (2019), more than 8.1 million people need food assistance in Ethiopia, and according to UNDP (2018a) and World Bank (2019), over 22 million people were below the national poverty line during 2017. As a result of food and nutritional insecurity, 57 percent of children under 5 years were anemic, 38 percent were stunted, 24 percent were underweighted, 13 percent were born with low birth weight, 10 percent were wasted, and 1 percent were overweight (USAID, 2018).

\section{RESEARCH METHODOLOGY}

\subsection{Description of the study area}

Walmara district is one of the districts under the Oromia special zone surrounding Finfinnee. The district lies between $8^{\circ} 50^{\prime}-9^{\circ} 15^{\prime} \mathrm{N}$ and $38^{\circ} 25^{\prime}-38^{\circ} 45^{\prime} \mathrm{E}$, having an area of 65,605 hectares. The altitude of the district is ranging from 2060 to 3380 masl with an average of 2400masl. About 61 percent of the district is highland and 39 
percent is mid-highland. The average annual rainfall of the district is $1,144 \mathrm{~mm}$, ranging from 795 to $1300 \mathrm{~mm}$. The annual temperature ranges from $6^{\circ} \mathrm{c}$ to $24^{\circ} \mathrm{c}$, with an average of $14^{\circ} \mathrm{c}$. According to the CSA population projection report, the population of the district was 112,498 (56,200 male and 56,298 female) during 2019. According to the information from the district's office of agriculture and rural development, the farming system of the district is characterized by both crop and livestock production. Wheat, barley, tef, pulses, and oilseeds are the major crops, while potatoes, cabbages, tomatoes, carrots, and onions are the major vegetable grown in the district respectively.

\subsection{Sampling procedure and sample size determination}

To select the required representative sample, a multistage sampling method was followed. The district was purposively selected at first. Second, the district was classified into highland and mid-highland based on the ecology. Third, four representative peasant associations, two from each ecology were randomly selected. In the fifth stage, systematic random sampling was used to sample the representative households.

To decide the required sample size, the rule of thumb followed. Based on this, the total sample size was 220 households including 10 percent contingency for non-response. The sample size from each kebele was selected based on the proportional sampling method which is determined using the following formula:

$$
n i=\frac{(N i)(n)}{\Sigma N i}
$$

Where $\quad \mathrm{ni}$ - the sample to be selected from $\mathrm{i}^{\text {th }}$ kebele

$\mathrm{Ni}$ - the total population living in $\mathrm{i}^{\text {th }}$ kebele.

$\Sigma \mathrm{Ni}$ - the summation of population living in selected four kebeles

$\mathrm{n}$ - total sample size for the district

Table 1. Sample distribution by peasant associations (Kebeles)

\begin{tabular}{llll}
\hline Name of Kebeles & Total household & Sample selected & Proportion \\
\hline Talacoo & 544 & 60 & $27.3 \%$ \\
Barfata Tokkoffaa & 777 & 86 & $38.9 \%$ \\
Bakakkaa and Qoree Oddoo & 325 & 36 & $16.3 \%$ \\
Waajituu Harbuu & 349 & 38 & $17.5 \%$ \\
\hline Total & 1995 & 220 & $100 \%$ \\
\hline
\end{tabular}

\subsection{Sources of data and method of collection}

Both data sources were used for this research. Structured and semi-structured questionnaires used to collect primary data from selected sample households. Secondary data collected by reviewing published journals, from records of the district's agricultural office, from the records of peasant association administration office, from the records of the farmers' training centers (FTCs), and etc.

\subsection{Method of data analysis}

Data analysis was performed using descriptive statistics and econometric models, and STATA version 15.3 was the package used to perform data analysis.

\subsubsection{Descriptive data analysis}

The included variables were summarized using percentage, mean, and standard deviation. T-tests and chi-square tests were executed to account for the statistical significance of the continuous and dummy variables respectively.

\subsubsection{Econometric data analysis}

Food security of the farm households was measured in daily calorie intake and converted to dummy, food secure if calorie consumption exceeding $2200 \mathrm{kcal}$ and food insecure if the calorie consumption is less than $2200 \mathrm{kcal}$ and used in the model. Logit was the model used and its functional form can be articulated as:

$$
\mathrm{Pi}=\mathrm{E}(\mathrm{D}=1 \mid \mathrm{Xi})=\frac{1}{1+e^{-(\beta o+\beta i X i)}}
$$

This can be simplified and expressed as:

$$
\mathrm{Pi}=\frac{1}{1+e^{-Z i}}
$$

Equation 3 is expressing the probability that the household is food secure and the probability that the household is food insecure can also be expressed as:

$$
1-\mathrm{Pi}=\frac{1}{1+e^{z i}}
$$

The odds ratio (the ratio of probability of food secure to food insecure) functionally expressed as: 


$$
\frac{P i}{1-P i}=\frac{1+e^{Z i}}{1+e^{-Z i}}=e^{Z i}
$$

The natural log. of the above eqn. can be articulated as:

$$
\mathrm{Li}=\ln \left[\frac{P i}{1-P i}\right]=\beta_{\mathrm{o}}+\beta_{1} \mathrm{X}_{1}+\beta_{2} \mathrm{X}_{2}+\beta_{3} \mathrm{X}_{3}+\ldots+\beta_{\mathrm{n}} \mathrm{X}_{\mathrm{n}}+\mathrm{U}_{\mathrm{i}}
$$

Where: $\quad \mathrm{Li}=\log$ of odds ratio

$\mathrm{Pi}=$ likelihood of being food secure

1-Pi $=$ likelihood of being food insecure

$\frac{\mathrm{Pi}}{1-\mathrm{Pi}}=$ the odds ratio

$\beta_{1}, \beta_{2}, \beta_{3}, \& \beta n=$ coefficients to be estimated

$\mathrm{X}_{\mathrm{i}}=$ independent variables included

$\mathrm{U}_{\mathrm{i}}=$ error term

\section{RESULT AND DISCUSSIONS}

\subsection{Descriptive results}

\subsubsection{Descriptive results of dummy variables}

As presented in Table 2, the result revealed that 68.6 percent of female-headed households and 92.4 percent of male-headed households were food secure. This indicates that male-headed households are more food secure than female-headed households. The Chi-square test also showed that the mean difference was statistically significant at a 1 percent probability level.

Table 2 also revealed that 895.9 percent of households having access to credit services and 76.1 percent of the households not having access to credit services were food secure. This shows that the mean food security status of households having access to credit services is better than that of households not having access to credit services. The chi-square test revealed that the mean difference was statistically significant at a 10 percent significance level.

Similarly, 90.5 percent of household heads having access to extension contact and 76.7 percent of the household heads not having access to extension contact were food secure. This indicates that mean food security status of households having access to extension contacts is better than those not having access to extension contacts. The chi-square test showed the mean difference was statistically significant at 5 percent.

The result also indicated that 82.7 percent of household heads whose crop field affected by crop pests, and 94.5 percent of the household whose crop field not affected by pests were food secure. From this result, the mean food security status of households whose crop fields not affected by crop pests was better than that of households whose crop fields were affected by pests. The chi-square test result also indicated that the mean difference is statistically significant at a 1 percent probability level.

\begin{tabular}{|c|c|c|c|c|c|c|c|c|c|c|c|c|}
\hline \multirow{3}{*}{$\begin{array}{l}\text { Food security } \\
\text { status }\end{array}$} & \multicolumn{12}{|c|}{ Variables } \\
\hline & \multicolumn{3}{|c|}{ Sex of the head } & \multicolumn{3}{|c|}{ Credit access } & \multicolumn{3}{|c|}{ Crop pests } & \multicolumn{3}{|c|}{ Extension contact } \\
\hline & Fem & Male & Total & No & Yes & Total & No & Yes & Total & No & Yes & Total \\
\hline Insecure & 11 & 14 & 25 & 5 & 20 & 25 & 6 & 19 & 25 & 7 & 18 & 25 \\
\hline Secure & 24 & 171 & 195 & 16 & 179 & 195 & 104 & 91 & 195 & 23 & 172 & 195 \\
\hline Total & 35 & 185 & 220 & 21 & 199 & 220 & 110 & 110 & 220 & 30 & 190 & 220 \\
\hline$\%$ & 16 & 84 & 100 & 9.5 & 90.5 & 100 & 50 & 50 & 100 & 13.6 & 86.4 & 100 \\
\hline $\operatorname{chi}^{2}(1)$ & & & 16.636 & & & 3.57 & & & 7.626 & & & 941 \\
\hline Pr. & & & $0.000 * * *$ & & & $0.059 *$ & & & $006^{* * *}$ & & & $26 * *$ \\
\hline
\end{tabular}

Table 2. Descriptive results for dummy variables

Note: $* * *$ and $* * *$ shows the significance levels at $10 \% 5 \%$ and $1 \%$

Source: Own household survey conducted during 2020

\subsubsection{Descriptive results of continuous variables}

According to the result in Table 3, the average age for food secure and non-secure household heads was 43.3 and 48.9 years with standard deviations of 9.75 and 9.7 respectively. It was negatively related to household food security, and from the t-test result, the mean difference was statistically significant at 5 percent. Similarly, the mean dependency ratio for both food secure and insecure households were 0.8 and 1.5 with standard deviations of 0.68 and 0.7 respectively. From this result, the dependency ratio is negatively related to household food security. The t-test result also showed the mean difference was statistically significant at 1 percent. Moreover, the mean family size for food secure and insecure households were 4.5 and 5.9 with standard deviations of 1.8 and 2.5 respectively. This result is showing that family size is negatively related to household food security. From the t-test result, the mean difference was statistically significant at 1 percent.

The average educational level for food secure and non-secure households were 4.3 and 2.3 years with standard 
deviations of 3.9 and 2.9 respectively. It is positively and significantly related to household food security at 5 percent. The result also showed that the mean livestock holding for food secure and insecure households were 7.2 and 5.5 with standard deviations of 4.1 and 2.1 respectively. This shows that livestock holding is positively and significantly related to household food security at a 5 percent significance level. Moreover, the mean land holding for food secure and insecure households were 1.5 and 0.6 with standard deviations of 1.2 and 0.6. This means the landholding is positively and significantly related to household food security at 1 percent.

The mean market distance for food secure and insecure households were 5.3 and 6.3 respectively. This is showing that market distance is negatively related to food security status. The t-test showed the mean difference was statistically significant at 5 percent. Similarly, the mean irrigation distance for food secure and insecure households were 2.1 and 2.6 respectively. This result is indicating that irrigation distance is negatively related to household food security status, and the t-test result was significant at 5 percent.

Table 3. Descriptive results for continuous variables

\begin{tabular}{llllllll}
\hline \multirow{2}{*}{ Variables } & \multicolumn{2}{c}{ Food secure } & \multicolumn{2}{c}{ Food insecure } & \multicolumn{2}{c}{ Combined } & \multirow{2}{*}{ T-value } \\
\cline { 2 - 7 } & mean & St.dev & mean & St.dev & mean & St.dev & $-2.7^{* *}$ \\
\hline Age of head (years) & 43.3 & 9.75 & 48.9 & 9.7 & 43.9 & 9.9 & -9.3 \\
Education of head (years) & 4.3 & 3.9 & 2.36 & 2.9 & 4.1 & 3.8 & $2.37^{* *}$ \\
Dependency & 0.82 & .68 & 1.5 & 0.7 & 0.9 & .7 & $-4.6^{* * *}$ \\
Livestock (TLU) & 7.2 & 4.1 & 5.5 & 2.1 & 7.0 & 4.0 & $2.04^{* *}$ \\
Family size (AE) & 4.5 & 1.8 & 5.9 & 2.5 & 4.6 & 1.9 & $-3.7^{* * *}$ \\
Off-farm income (000 Bir) & 7.5 & 10.2 & 8.9 & 9.3 & 7.7 & 10.1 & -0.67 \\
Market distance (KM) & 5.3 & 2.2 & 6.3 & 2.2 & 5.4 & 2.2 & $-2.16^{* *}$ \\
Irrigation distance (KM) & 2.1 & 0.8 & 2.6 & .8 & 2.2 & .8 & $-2.61^{* *}$ \\
\hline Land owned (hectares) & 1.5 & 1.2 & 0.6 & 0.6 & 1.5 & 1.2 & $3.9^{* * *}$ \\
\hline
\end{tabular}

Note: $* *$ and $* * *$ shows the significance levels at $5 \%$ and $1 \%$

Source: Own household survey conducted during 2020

\subsection{Econometric results}

To do logistic regression, food security measured in the daily calorie intake method was used as a dummy dependent variable. The households with individual daily calorie intake exceeding 2200 kilocalorie were considered food secure and the rest were taken as food insecure. Before running the model, variance inflation factor (VIF) was tested to check for multicollinearity, and the mean VIF was 1.25. Accordingly, sex of the head, livestock holding, landholding, access to extension contact, irrigation use, and credit access positively and significantly affected household food security status, while the family size and dependency ratio negatively and significantly affected household food security status.

Sex of the household head: As expected, the sex of the household head affected household food security positively and significantly at a 5 percent probability level. This means male-headed households are more likely to be food secure than female-headed households. The possible reasons might be due to physical, socio-cultural, and time constraints that females are facing as compared to males, and these contributed to the food insecurity status of female-headed households. This result is consistent with the findings of Ahmed (2015), Mustapha et al. (2018), and Sani and Kemaw (2019).

Family size AE: In contrary to the hypothesis, adult equivalent family size negatively and significantly affected household food security at a 1 percent probability level. This result is indicating that the households with larger adult equivalent family size are less likely to be food secure compared to the households with smaller family size. This might be because adding family members to limited resources may cause scarcity and lead the family to food insecurity status. This result is consistent with the findings of Mesele et al. (2018), Mustapha et al. (2018), and Temesgen (2019).

Dependency ratio: As expected, the dependency ratio affected household food security negatively and significantly at a 5 percent significance level. Households with a high dependency ratio were less likely to be food secure compare to households with a less dependence ratio. The reason for this is that as dependent family members increase, it will impose pressure on household resources. Additionally, as dependents increase per family, there will be a higher burden on the active family members and this, in turn, affects households' food security status. This result is consistent with the results reported by Goshu (2016), Dawit and Zeray (2017), Mustapha et al. (2018), and Akukwe (2020).

Livestock holding in TLU: As hypothesized, livestock holding affected household food security positively and significantly at a 5 percent significance level. From this result, the households having more livestock are more likely to be food secure compared to those households holding lesser numbers of livestock. The reason for this was the multi-dimensional contributions of livestock products and by-products in combating household food insecurity. Livestock serves as a source of food as well as a source of income to purchase food during the time of food shortage. This result is consistent with the findings reported by Haileyesus (2019), Mesele et al. (2018), 
Habtewold (2018).

Land owned: Land owned also affected household food security positively and significantly at a 5 percent significance level. This result is consistent with the hypothesis and the households having more land are more likely to be food secure than those households owning lesser land. This is because households with a wider area of land would have the possibility to produce more or diverse agricultural products which would diversify consumption either through the product that they produce or through the additional income that they would get and hence contribute to improve food security. This result is consistent with the findings reported by Mustapha et al. (2018), Mesele et al. (2018), Habtewold (2018), and Haileyesus (2019).

Access to extension services: This variable positively and significantly affected household food security at a 5 percent significance level. This means that households getting extension services are more likely to be food secure compared to households without the services. This is because agricultural extension plays a significant role in improving production, productivity, food security, and rural livelihood. This result is also consistent with the findings reported by Mustapha et al. (2018) and Haileyesus (2019).

Access to credit services: As expected, this variable also affected household food security positively and significantly at a 10 percent significance level. The households having access to credit services are more likely to be food secure than a household without the services. This is because of those households having access to credit services can easily buy agricultural inputs like improved seed, fertilizer, labor, rent farmland, etc., and improve their production and productivity which improves their food security status. This result is also consistent with the findings reported by Mustapha et al. (2018), Habtewold (2018), and Sami and Kemaw (2019).

Participation in irrigation: As expected, participation in irrigation positively and significantly affected household food security at a 1 percent significance level. From this result, irrigation user households are more likely to be food secure than households not using irrigation. The reason for this is because participation in irrigation enables the households to efficiently use the available agricultural inputs like land, labour, and other resources during the off (dry) season and increase their production. This result is also consistent with the results reported by Hamda (2016), Agena (2017), Ngema et al. (2018), Mesele et al. (2018), and Sami and Kemaw (2019).

Table 4. Logit model result (Factors affecting household food security status)

\begin{tabular}{llll}
\hline Variables & Coef. & St. Err. & t-value \\
\hline Sex of the household head & 1.693 & 0.721 & $2.35^{* *}$ \\
Age of the head (years) & -0.020 & 0.037 & -0.55 \\
Education of the head (years) & 0.077 & 0.108 & 0.71 \\
Family size (AE) & -0.638 & 0.206 & $-3.10^{* * *}$ \\
Dependence ratio & -1.272 & 0.497 & $-2.56^{* *}$ \\
Livestock holding (TLU) & 0.306 & 0.122 & $2.51^{* *}$ \\
Land owned (hec.) & 1.243 & 0.482 & $2.58^{* *}$ \\
Distance of irrigation site (KM) & -0.694 & 0.448 & -1.55 \\
Off-farm income (Birr) & 0.000 & 0.000 & -0.83 \\
Occurrence of crop diseases & -0.620 & 0.712 & -0.87 \\
Access to extension contact & 1.644 & 0.785 & $2.09^{* *}$ \\
Market distance (KM) & -0.145 & 0.155 & -0.94 \\
Access to irrigation services & 2.508 & 0.923 & $2.72^{* * *}$ \\
Access to credit service es & 1.730 & 0.936 & $1.85^{*}$ \\
Constant & 3.139 & 2.826 & 1.11 \\
\hline Mean & 0.886 & St. dev. & 0.318 \\
Pseudo $\mathrm{R}^{2}$ & 0.516 & No. obs. & 220.0 \\
Chi-square & 80.333 & Pr. $>$ chi & 0.000 \\
\hline
\end{tabular}

$* * * p<0.01, * * p<0.05$ and $* p<0.1$ (significance levels at $1 \%, 5 \%$ and $10 \%$ )

Source: Computed from own survey data of 2020

\section{CONCLUSION AND RECOCCEMDATIONS}

The study was conducted with the main objective of assessing factors affecting household food security status in central Ethiopia using evidence from Walmara district, Oromia. Both primary and secondary data were used. Primary data were collected from 220 sample households and secondary data were collected from journals, district office of agriculture, peasant administration offices, etc. The multi-stage sampling technique was the sampling method used. Descriptive and econometric data analyses were performed, and logistic regression was the model used.

From the descriptive result, sex of the household head, access to credit services, occurrence of crop pests, access to extension contact, age of the household head, education level of the household head, dependency ratio, livestock holding, family size, market distance, distance from irrigation site and land ownership were the 
variables that significantly related to household food security.

The logistic regression results also revealed that household food security status was significantly affected by eight variables. These variables were the sex of the head, family size, dependence ratio, livestock holding, land owned, access to extension contacts, access to irrigation services, and access to credit services. Among these variables, sex of the household head, livestock holding, land owned, access to extension contacts, access to irrigation services, and access to credit services positively affected household food security status, while family size and dependency ratio negatively affected household foods security status.

Finally, intervention policies focusing on the provision of gender-based training, construction of small-scale irrigation facilities, promoting mixed farming of crop and livestock, and availing institutions providing financial and technical services to farm households are recommended as they contribute more in improving the food security status of farm households.

\section{REFERENCES}

Agena M.A., 2017. Impact of small-Scale Irrigation on Farmers' Cropping System Choice, Productivity and Food Security in Meskan District of Southern Ethiopia (Doctoral dissertation, Haramaya University).

Ahmed, M. 2015. Determinants of Household Food Security and Coping Strategies: The Case of Bule-Hora District, Borana Zone, Oromia, Ethiopia. European Journal of Food Science and Technology, 3, 30-44.

Akukwe T.I., 2020. Household food security and its determinants in agrarian communities of southeastern Nigeria. Agro-Science, 19 (1), 54-60. DOI: https://dx.doi.org/10.4314/as.v19i1.9

CSA, 2019. Central Statistical Agency. The Federal Democratic Republic of Ethiopia, Central Statistical Agency. Population projection report

Dawit, D. and Zeray, N., 2017. Determinants of rural household food security in Wolaita Zone: the case of Humbo Woreda. Journal of Poverty, Investment \& Development 32, 65-82

FAO and ECA, 2018. Regional Overview of Food Security and Nutrition. Addressing the threat from climate variability and extremes for food security and nutrition. Accra. $116 \mathrm{p} \mathrm{p}$

FAO, 2019. Early Warning Early Action report on food security and agriculture (April-June 2019). Rome. 62 pp. License: CC BY-NC-SA 3.0 IGO

FAO, IFAD, UNICEF, WFP and WHO. 2018. The State of Food Security and Nutrition in the World 2018. Building climate resilience for food security and nutrition. Rome, FAO. License: CC BY-NC-SA 3.0 IGO.

FAO, IFAD, UNICEF, WFP and WHO. 2020. In Brief to The State of Food Security and Nutrition in the World 2020. Transforming food systems for affordable healthy diets. Rome, FAO.

Goshu, M.T., 2016. Determinants of Rural Food Security and Child Nutrition: The Case Study of Gubalafto District of Amhara Regional State, Ethiopia (Unpublished PhD thesis). Department of Economics, Aligarh Muslim University Aligarh, India

Habtewold, T.M., 2018. Determinants of food security in the Oromiya Region of Ethiopia. In Economic Growth and Development in Ethiopia (pp. 39-65). Springer, Singapore.

Haileyesus, M., 2019. The Contribution of Irrigation to Food Security in Farta Woreda, South Gondar Zone, Amhara National Regional State, Ethiopia (MSc Thesis, Addis Ababa University).

Hamda, A.K., 2016. Impact of Small-Scale Irrigation on Household's Food Security in Fentale District East Showa Zone of Oromia National Regional State, Ethiopia (MSc Thesis, Haramaya University).

Mesele, K.A., Suneetha, P. and Tigga, A., 2018. Determinants of household food security in southern Tigray, northern Ethiopia.

Mustapha, M., Kamaruddin, R.B. and Dewi, S., 2018. Factors affecting rural farming household's food security status in Kano, Nigeria. International Journal of Management Research and Reviews, 8(9), p.1.

Ngema, P.Z., Sibanda, M. and Musemwa, L., 2018. Household food security status and its determinants in Maphumulo local municipality, South Africa. Sustainability, 10(9), p.3307.

Sani, S. and Kemaw, B. 2019. Analysis of Rural Households Food Security in Western Ethiopia Food and Nutrition Sciences, 10, 249-265.

Temesgen, B.T., 2019. Determinants of Small-Scale Irrigation Use and Its Implication on Poverty Reduction: Empirical Evidences from Bogena River Catchment in Awabel District, East Gojjam, Ethiopia (MSc Thesis, Addis Ababa University).

UNDP, 2018a. Ethiopia's Progress Towards Eradicating Poverty: Implementation of the third United Nations decade for Eradication of Poverty (2018 - 2027).

USAID, 2018. Global Food Security Strategy (GFSS) Ethiopia Country Plan, 22. The U.S Government's Global Hunger and Food Security Initiative.

World Bank, 2018. Ethiopia’s Economic Update. The Inescapable Manufacturing-Services Nexus: Exploring the potential of distribution services.

World Bank, 2019. An Overview of Ethiopian Economy. World Bank's goals of promoting rapid economic growth and improving service delivery. 
World Vision, 2018. East Africa's hunger crisis situation report. Responding to Food Insecurity in Ethiopia. March 01-31, 2018. 